\title{
PENGEMBANGAN MODUL FISIKA BERDASARKAN HAMBATAN BELAJAR SISWA
}

\section{DEVELOPMENT OF THE PHYSICAL MODULE BASED ON OBSTACLES OF STUDENT LEARNING}

\author{
Widya Wati ${ }^{1}$, Chairul Amriyah ${ }^{2}$, Trie Wydia Astuti ${ }^{3}$ \\ ${ }^{1,3}$ Prodi Pendidikan Fisika Fakultas Tarbiyah dan Keguruan Universitas Islam Negeri Raden Intan \\ Lampung \\ ${ }^{2}$ Prodi Bimbingan Konseling dan Pendidikan Islam Fakultas Tarbiyah dan keguruan Universitas Islam \\ Negeri Raden Intan Lampung \\ Email:triewydiaa@gmail.com
}

Diterima: 3 Februari 2019. Disetujui: 29 Februari 2019. Dipublikasikan: 29 Maret 2019

\begin{abstract}
The purpose of this study is to produce in the form of modules based on student learning barries in object elasticity and Hooke's law is valid and interesting. This study uses a model ( $R$ \& D) from Borg and Gall which consists of 10 steps and is limited to 7 steps. Based on the results of product validation, it can be concluded that the module based on student learningbarriesin object elasticity and Hooke's law is stated to be very valid and usable. Scores from material experts $95.83 \%$, scores from media experts $82.96 \%$, and scores from expert learning $80.00 \%$. Then, the products were tested in small groups with an average score of $88.08 \%$ attractiveness. Furthermore, the trial of large groups in school I obtained a score of $88.92 \%$ and scores from school II 83.32\%, the assessment of teacher's responses scored $97.20 \%$. Based on the results obtained, it can be concluded that the module based on student learning barriesin object elasticity and Hooke's law is very interesting and can be used as a learning resource.
\end{abstract}

Keywords: object elasticity and Hooke's Law, student Learning Obstacles, module

\begin{abstract}
Abstrak: Tujuan dari penelitian ini yakni untuk menghasilkan produk berupa modul berdasarkan hambatan belajar siswa pada materi elastisitas benda dan hukum Hooke yang valid dan menarik. Penelitian ini menggunakan model (R\&D) dari Borg and Gall yang terdiri dari 10 langkah dan dibatasi menjadi 7 langkah.Berdasarkan hasil validasi produk, dapat disimpulkan bahwa modul berdasarkan hambatan belajar siswa pada materi elastisitas benda dan hukum Hooke dinyatakan sangat valid dan dapat digunakan. Skor dari ahli materi 95,83\%, skor dari ahli media 82,96\%, dan skor dari ahli pembelajaran 80,00\%. Kemudian, produk diuji cobakan dalam kelompok kecil dengan rata-rata skor kemenarikan $88,08 \%$. Selanjutnya, uji coba kelompok besar di sekolah I memperoleh skor 88,92\% dan skor dari sekolah II 83,32\%, penilaian respon guru memperoleh skor 97,20\%. Berdasarkan hasil yang diperoleh bahwa dapat disimpulkan bahwa modul berdasarkan hambatan belajar siswa pada materi elastisitas benda dan hukum Hooke sangat menarik dan dapat digunakan sebagai sumber belajar.
\end{abstract}

(C) 2019 Unit Riset dan Publikasi Ilmiah FTK UIN Raden Intan Lampung

Kata kunci: elastisitas benda dan Hukum Hooke, hambatan belajar siswa, modul

\section{PENDAHULUAN}

Pembelajaran mengedepankan

yang pemahaman

maka akan menimbulkan pembelajaran yang kurang arti dari memahami konsep.Kemudian, jika proses belajar

hanya tekstual proses dalam suatu yang hanya mengedepankan hasil maka, siswa tersebut akan memahami konsep tidak secara keseluruhan atau siswa terebut belajar secara pasif. Hal itu salah satunya diakibatkan dari sumber belajar yang tidak terstruktur atau dari kegiatan 
pembelajaran yang diterima siswa (Dedy \& Sumiyaty, 2017). Keadaan dalam pembelajaran tersebut merupakan tiga komponen yang berhubungan antara siswa, buku atau materi, juga guru itu sendiri (Cavalcanti \& Lins, 2013).

Pembelajaran fisika mengedepankan pemahaman secara mendalam dimulai dari hakikat fisika itu sendiri, proses, sikap dan produk fisika itu sendiri. Jadi, pada pembelajaran fisika tidak hanya mencakup rumus dan teori yang berasal dari sumber belajar (Rahayu, Prihandono, \& Gani, 2017). Pelajaran fisika akan mudah dipahami jika dalam proses pembelajarannya, guru menggunakan variasi dalam menyampaikan materi dengan menggunakan benda-benda di sekitar untuk memberikan stimulus yang berhubungan dengan konsep yang diberikan kepada siswa. Hal tersebutdiutarakan oleh Badan Standar Nasional Pendidikan (BSNP) tahun 2006 bahwa dalam pembelajaran fisika memiliki tujuan yaitu untuk mengembangkan kemampuan siswa dalam memproses pelajaran dalam bentuk berpikir analisis induktif dan deduktif, yakni dari menganalisis bagian khusus maupun umum dari konsep fisika tersebut. Analisis tersebut dengan menggunakan konsep, hakikat dan prinsip fisika yang mana hal tersebut dapat digunakan untuk menyelesaikan suatu masalah dalam fisika(Wati \& Fatimah, 2016).

Ketika proses pembelajaran, guru harus bisa membuat persiapan rancangan untuk mengatasi hambatan belajar yang dialami siswa (Suryana, Pranata, \& Apriani, 2012). Hambatan belajaryang biasa disebut dengan learning difficulty adalah kendala dalam belajar yang membuat siswa sulit untuk memahami pelajaran dan melakukan kegiatan belajar secara maksimal dan efektif (Jamaris, 2015).
Hambatan belajar adalah suatu kondisi dimana siswa tidak dapat mengendalikan dan mencerna materi pelajaran dengan mudah sehingga tujuan pembelajaran tidak tercapai dengan maksimal.Hambatan belajar merupakan sumber masalah yang terbagi menjadi tiga macam, yaitu dari sumber kesiapan mental (ontogenik), sumber dari pemberian materi oleh guru (didaktis) dan pengetahuan awal yang terbatas pada konteks tertentu (epistemologi) (Lestari, Rusnayati, \& Wijaya, 2017). Hambatan belajar yang dialami siswa bisa terjadi dikarenakan terdapat dua faktor yaitu faktor internal dan faktor eksternal.Faktor internal bisa berasal dari peran orang tua dan minat belajar siswa. Sedangkan faktor eksternal bisa berasal dari lingkungan, buku atau sumber belajar maupun dari program belajar (Arslan, Baran, \& Okumus, 2011). Hasil survey dari lembaga TIMSS (Trends International Mathematics and Science Study) pada tahun 2015 menyebutkan bahwa mutu dari pendidikan di Indonesia berada di 10 besar terawah dari negara lain seperti negara Asia dan Eropa (Rahmawati, 2016). Salah satu yang menyebabkan mutu dari pendidikan di Indonesia rendah adalah dari kualitas sumber belajar yang digunakan (Anwari, 2017).

Hasil pra penelitian di beberapa SMA di Bandar Lampung pada tahun ajaran 2017/2018, ditemukan hambatan belajar siswa dikarenakan belum sepenuhnya memahami konsep fisika, faktor yang mempengaruhi adalah salah satunya berasal dari diri siswa sendiri, lingkungan dan pengetahuan awal yang terbatas. Menurut pendapat salah satu guru fisika di beberapa SMA di Bandar Lampung juga mengatakan hambatan belajar siswa juga dipengaruhi dari rasa malas siswa untuk memperhatikan guru ketika pembelajaran dan minat belajar fisika siswa yang rendah serta memahami 
materi yang terlalu banyak rumus atau persamaan.

Menurut hasil wawancara yang telah dilakukan dengan guru mata pelajaran fisika di SMA yang ada di Bandar Lampung, didapati bahwa guru belum menggunakan sumber atau media belajar yang dibuat berdasarkan hambatan belajar siswa untuk penunjang pembelajaran. Menurut studi pustaka yang dilakukan dari referensi jurnal-jurnal penelitian bahwa terlihat pada kondisi di lapangan, bahwa masih banyak guru yang menggunakan sumber atau media belajar yang tersedia dan siap pakai tanpa merencanakan dan meyusunnya secara mandiri. Hal itu dapat menyebabkan kemungkinan pada sumber belajar yang digunakan tidak kontekstual, kurang meperhatikan kondisi siswa, tidak menarik dan terkesan monoton (Fatikhah \& Izzati, 2015).

Modul saat ini terbagi dalam dua kategori, yaitu modul yang bersifat cetak dan modul digital (Irwandani, Latifah, Asyhari, Muzannur, \& Widayanti, 2017). Modul adalah bentuk sumber belajar yang disusun secara sistematis. Modul tersebut mencakup pengalaman belajar dan didesain untuk siswa menguasai tujuan belajar secara spesifik(Rahdiyanta, 2009). Modul adalah salah satu sumber atau media belajar yang bertujuan untuk membuat siswa bisa menjadi lebih mandiri dalam belajar dan dilengkapi petunjuk agar dapat belajar sendiri (Setiyadi, Ismail, \& Gani, 2017).

Berdasarkan uraian permasalahan diatas, maka dirasa perlu peneliti melakukan penelitiandan pengembangan modul. Kebaruan dari penelitian ini, modul yang dikembangkan dibuat berdasarkan hambatan belajar siswa pada pelajaran fisika khususnya pada materi elastisitas benda dan hukum Hooke di kelas X SMA.

\section{METODE PENELITIAN}

Tujuan dari penelitian ini adalah mengembangkan modul yang berdasarkan hambatan belajar siswa yang valid dan menarik.Penelitian ini menggunakan penelitian dan pengembangan model dari Borg and Gall. Langkah-langkah dalam penelitian ini terdiri 10 langkah yaitu potensi dan masalah, pengumpulan data, desain produk, validasi desain, revisi desain, uji coba produk, revisi produk, uji coba pemakaian, revisi produk, dan produksi masal (Sugiyono, 2012).

Menurut uraian langkah-langkah penelitian dan pengembangan diatas, peneliti membatasi 10 langkah penelitian hanya sampai langkah ke-7 dikarenakan berdasarkan tujuan penelitian hanya melihat kevalidan dan kemenarikan dari produk yang dikembangkan. Langkah yang pertama yaitu potensi dan masalah, masalah yang didapat dari hasil pra penelitian dan studi pustaka yang dilakukan dengan membaca referensi jurnal-jurnal penelitian yang ada. Dari data tersebut untuk dijadikan masalah dasar untuk penunjang penelitian.

Setelah masalah sudah ditemukan, maka langkah selanjutnya mengumpulkan data berupa informasi buku atau sumber belajar yang digunakan dan hambatan belajar yang muncul ketika pembelajaran. Pengumpulan data tersebut dengan melakukan wawancara dengan guru mata pelajaran fisika, menyebarkan angket ke siswa dan juga menyebarkan angket terbuka untuk guru.Setelah data dan informasi sudah terkumpul dan dianalisis, maka selanjutnya mendesain produk awal yakni berupa modul berdasarkan hambatan belajar siswa yang ditemukan.

Langkah selanjutnya validasi desain yang dilakukan oleh beberapa ahli. Validator ahli terdiri dari ahli materi, ahli media, dan ahli pembelajaran. Ahli materi menilai sajian materi dan kesesuaian materi, ahli media menilai indikator dari 
tampilan dan isi modul, sedangkan, ahli pembelajaran menilai dari segi kesesuaian hambatan belajar yang disajikan dalam modul. Setelah melakukan validasi ke para ahli dan mendapatkan saran dan perbaikan, maka dilakukan revisi sesuai dengan saran dan revisi oleh pada validator.

Setelah melakukan revisi produk, maka langkah selanjutnya uji coba produk yang bertujuan untuk mengumpulkan data mengenai respon siswa dan guru terhadap kemenarikan modul. Pengujian produk dilakukan dengan 2 pengujian.Yang pertama uji kelompok kecil dan yang kedua uji coba lapangan responden 10-20 orang, uji coba lapangan dilakukan dengan responden 30-40 orang. Setelah uji coba produk, mendapat saran dan perbaikan, maka dilakukan revisi sesuai dengan saran dan perbaikan untuk kualitas modul yang lebih dan dapat digunakan.

Dalam pengumpulan data, instrumen yang digunakan berupa lembar validasi.Lembar validasi menggunakan skala Likert dan terdiri dari lembar validasi ahli materi, lembar validasi ahli media, lembar validasi ahli pembelajaran, lembar penilaian respon siswa dan lembar penilaian respon guru.

Teknik analisis data yang digunakan untuk menghitung persentase skor kevalidan dari setiap indikator menggunakan rumus sebagai berikut(Irwandani et al., 2017):

$$
\bar{X}=\frac{\sum x}{n}
$$

Kemudian untuk menghitung persentase skor kemenarikan dari responden menggunakan rumus sebagai berikut(Indrawati, 2013)

$$
\mathrm{P}=\frac{\sum \text { skor yang diperoleh }}{\text { skor maksimal }} \times 100 \%
$$

Setelah mendapat skor persentase berupa angka, kemudian mengubah angka persentase skor kevalidan tersebut menjadi nilai kualitatif dengan kriteria sebagai berikut:(Asyhari \& Silvia, 2016)

\begin{tabular}{|c|c|c|}
\hline No. & Interval & Kriteria Validasi \\
\hline 1 & $0 \%-20 \%$ & Sangat Kurang \\
\hline 2 & $21 \%-40 \%$ & Kurang \\
\hline 3 & $41 \%-60 \%$ & Cukup \\
\hline 4 & $61 \%-80 \%$ & Valid \\
\hline 5 & $81 \%-100 \%$ & Sangat valid \\
\hline
\end{tabular}

Tabel 1. Kriteria Penilaian Produk kevalidan, pada skor kemenarikan dari penilaian responden yang berupa angka diubah menjadi nilai kualitatifdengan skala interpretasi sebagai berikut (Yuberti, 2015):

Tabel 2. Skala Interpretasi Penilaian Respon

\begin{tabular}{cc}
\hline Interval (\%) & Kriteria \\
\hline $80<\mathrm{X} \leq 100$ & Sangat Menarik \\
$60<\mathrm{X} \leq 80$ & Menarik \\
$40<\mathrm{X} \leq 60$ & Cukup Menarik \\
$20<\mathrm{X} \leq 40$ & Kurang Menarik \\
$0<\mathrm{X} \leq 20$ & Tidak Menarik \\
\hline
\end{tabular}

\section{HASIL DAN PEMBAHASAN}

\section{a. Hasil}

Berdasarkan uraian dari langkahlangkah penelitian dan pengembangan, didapati hasil yaitu produk berupa modul berdasarkan hambatan belajar siswa kelas $X$. Langkah pertama yaitu potensi dan masalah.Dari hasil potensi masalah diperoleh masalah bahwa hambatan belajar siswa masih sering muncul pada pembelajaran fisika dan penggunaan media atau sumber belajar seperti modul belum digunakan dan kurang bervariasi.

Langkah selanjutya, pengumpulan data yang telah dilakukan dengan wawanca dan penyebaran angket kepada siswa dan guru diperoleh bahwa hambatan belajar siswa meliputi pemahaman konsep yang kurang, rendahnya minat belajar fisika siswa, kemudian kurangnya siswa dalam pelatihan atau pemecahan soal/masalah serta pengetahuan awal siswa yang terbatas. Dari hasil pra penelitian pula diperoleh bahwa guru hanya menggunakan buku paket yang tersedia di sekolah kemudian juga guru belum 
menggunakan media atau sumber belajar yang dibuat sendiri berdasarkan hambatan belajar siswa sebagai penunjang pembelajaran fisika.

Setelah masalah ditentukan dan langkah pengumpulan data telah dilakukan, maka selanjutnya mendesain produk awal berupa modul berdasarkan hambatan belajar siswa. Modul didesain menggunakan aplikasiCorel Draw X4 dan Microsoft Word 2010.Modul dibuat berdasarkan silabus pada kurikulum 2013, kompetensi inti (KI) dan kompetensi dasar (KD).

Setelah desain produk awal sudah dibuat, kemudian melakukan validasi untuk mengetahui tingkat kevalidan dari modul tersebut dengan ahli materi, ahli media, dan ahli pembelajaran.Ahli materi dan ahli media masing-masing terdiri dari dua validator, sedangkan ahli pembelajaran terdiri dari satu validator. Hasil dari validasi ahli materi dengan mengisi lembar validasi yang berisi 15 pernyataan dari 4 indikator penilaian. Hasil skor disajikan dalam bentuk grafik pada gambar 1 sebagai berikut:

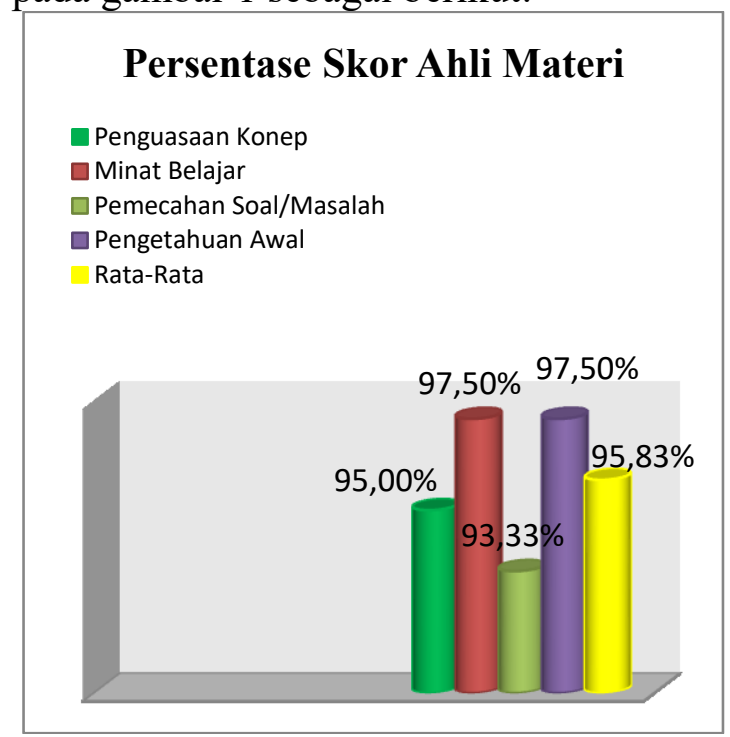

Gambar 1. Grafik Skor Ahli Materi

Kemudian hasil dari validasi ahli media yang dilakukan dengan mengisi lembar validasi berisi 20 pernyataan dari 4 indikator. Hasil skor disajikan dalam bentuk grafik pada gambar 2 sebagai berikut:

\section{Persentase Skor Ahli Media}
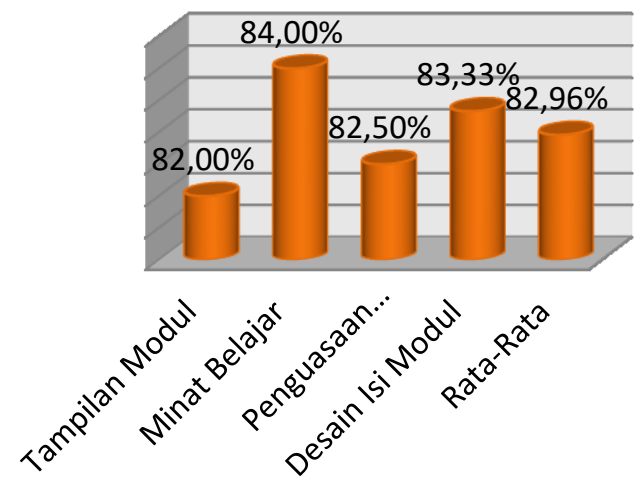

Gambar 2. Grafik Skor Ahli Media

Selanjutnya hasil dari validasi ahli pembelajaran yang dilakukan dengan mengisi lembar validasi berisi 9 pernyataan dari 4 indikator. Hasil skor dari ahli pembelajaran disajikan pada bentuk grafik pada gambar 3 sebagai berikut:

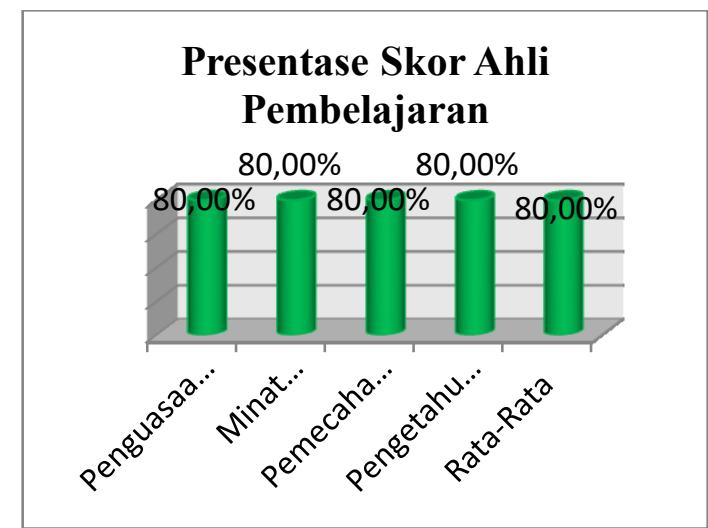

Gambar 3.Grafik Skor Ahli Pembelajaran

Setelah langkah validasi desain telah dilakukan, maka langkah selanjutnya adalah pengujian produk.Pengujian produk dilakukan dengan 2 tahap uji coba yakni uji coba kelompok kecil dan uji coba lapangan.Uji coba kelompok kecil dilakukan dengan mengisi lembar penilaian respon siswa.Uji ini dilakukan dengan 22 responden dari kedua sekolah. Hasil skor dari uji coba kelompok kecil disajikan dalam bentuk grafik pada gambar 4 sebagai berikut: 


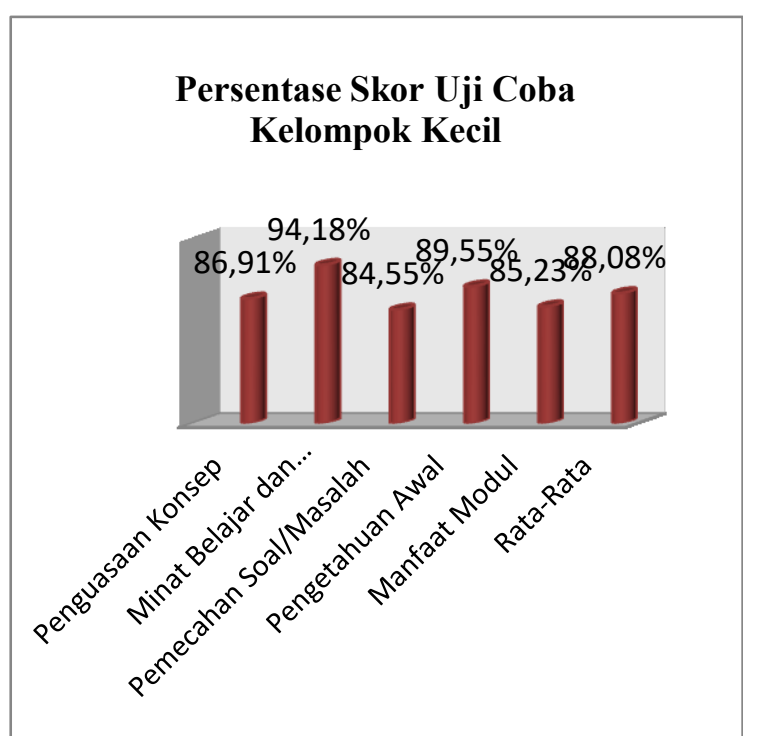

Gambar 4. Grafik Skor Uji Coba Kelompok Kecil

Selanjutnya uji coba lapangan yang dilakukan dengan mengisi lembar penilaian respon siswa. Uji ini dilakukan dengan responden berjumlah 60 responden dari kedua sekolah. Hasil skor uji coba lapangan disajikan dalam bentuk grafik pada gambar 5 sebagai berikut:

\section{Persentase Skor Uji Coba Lapangan}

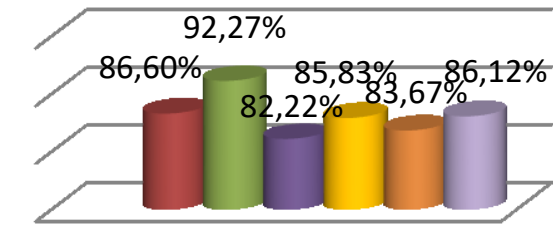

- Penguasaan Konsep

- Minat Belajar dan Tampilan Modul

- Pemecahan Soal/Masalah

Pengetahuan Awal

Manfaat Modul

Rata-Rata

Gambar 5.Grafik Skor Uji coba Lapangan

Penilaian respon guru dengan melakukan pengisian lembar penilaian yang berisi 15 pernyataan dari 5 indikator penilaian.Penilaian dilakukan oleh guru mata pelajaran fisika di beberapa SMA di Bandar Lampung. Hasil skor penilaian respon guru disajikan dalam bentuk grafik pada gambar 6 sebagai berikut:

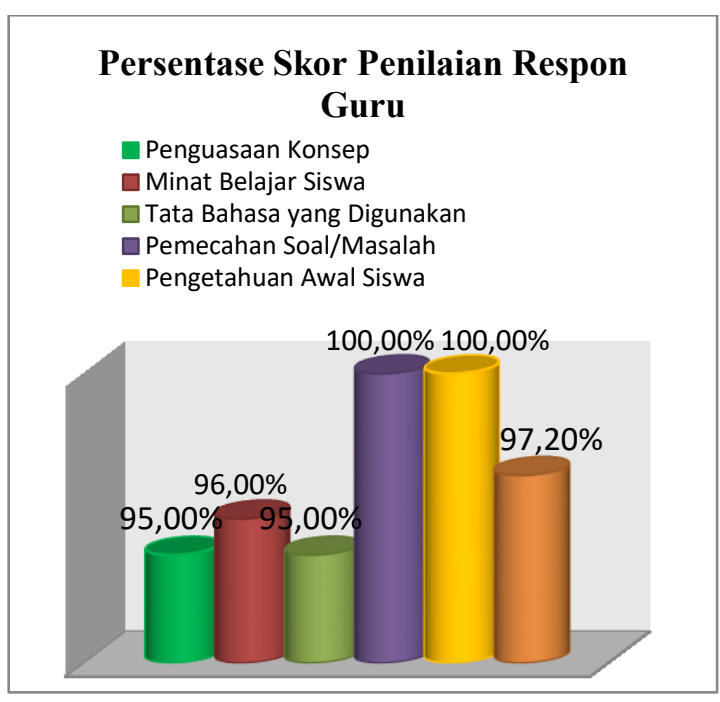

Gambar 6.Grafik Skor Penilaian Respon Guru.

Berdasarkan hasil dari uji coba produk diperoleh hasil persentae skor $\geq 80 \%$ maka dengan itu produk berupa modul yang dikembangkan termasuk dalam kriteria sangat menarik, baik dari uji coba kelompok kecil maupun uji coba lapangan.

\section{b. Pembahasan}

Hasil dari penelitian ini ditujukan untuk menjawab rumusan masalah.Data hasil dari validasi ahli materi memperoleh persentase skor yang masuk dalam kriteria sangat valid. Pada validasi ahli materi dari seluruh indikator penilaian memperoleh persentase rata-rata $>80 \%$ yaitu sebesar 95,83\%. Untuk itu modul berdasarkan hambatan belajar siswa sudah sesuai dengan materi dan sesuai dengan kurikulum 2013.

Kesesuaian materi berdasarkan indikator penilaian.Pada indikator penguasaan konsep siswa, materi yang disajikan sudah sesuai dengan pemahaman siswa dan materi yang disajikan sesuai dengan kurikulum 2013.Pada indikator minat belajar, materi yang disajikan tidak berlebihan dalam penulisan, dan keterkaitan dengan masalah dengan materi telah sesuai.Pada indikator pemecahan soal/masalah, penyajian contoh soal dan latihan sudah sesuai, dan pada indikator pengetahuan 
awal, keterkaitan konsep sebelumnya dengan materi yang disajikan telah sesuai. Kemudian, pada penilaian ahli media memperoleh persentse skor rata-rata dari semua indikator penilaian sebesar $82,96 \%$. Untuk itu modul berdasarkan hambatan belajar sudah valid dalam hal penyajiannya.

Penyajian dalam modul telah sesuai berdasarkan indikator penilaian.Pada indikator tampilan modul telah sesuai dengan standar modul, dan kemenarikan tampilan, warna, gambar dan ilustrasi.Pada indikator minat belajar juga telah sesuai, yakni kesesuaian dari penempatan kolom informasi dan pemberian warna pada judul modul.Pada indikator pengetahuan awal dan pemecahan soal telah sesuai, yakni dari segi kesesuaian tampilan kolom ilmuwan, gambar dan ilustrasi sesuai dengan perkembangan siswa.Dan pada indikator desain isi modul juga telah sesuai.Kesesuaian desain isi yakni penggunaan variasi huruf dan jenis huruf, penggunaan warna yang kontras, penempatan judul dan subjudul dan konsistensi dari jenjang judul-judul yang disajikan.

Penilaian dari ahli pembelajaran memperoleh persentase skor rata-rata yakni sebesar $80,00 \%$. Untuk itu modul berdasarkan hambatan belajar telah sesuai dengan hambatan belajar yang disajikan dalam modul.

Pada indikator penilaian penguasaan konsep, materi yang disajikan telah sesuai dengan pemahaman siswa.Pada indikator minat belajar siswa, modul yang dikembangkan telah sesuai untuk mengarahkan siswa agar belajar secara mandiri, dan penggunaan modul dengan tampilan menarik. Pada indikator pemecahan soal/masalah telah sesuai dalam penggunaan kolom tips yang membantu siswa dalam memecahkan soal dan contoh soal latihan melatih kemampuan pemecahan masalah. Pada indikator pengetahuan awal telah sesuai dengan materi yang disajikan dengan konsep sebelumnya yang menunjang siswa memahami materi elastisitas benda dan hukum Hooke.

Penilaian respon siswa dan guru memperoleh persentase skor rata-rata masing-masing $86,12 \%$ dan $97,20 \%$. Dengan demikian, penilaian respon siswa dan guru dari seluruh indikator penilaian termasuk dalam kriteria sangat menarik dalam segi tampilan dan keakuratan materi yang disajikan.

Pada penilaian respon guru dari indikator penguasaan konsep, materi yang disajikan telah sesuai dengan kompetensi dasar (KD) dan tujuan pembelajaran, kesesuaian penyajian materi dengan kurikulum 2013. Pada indikator minat belajar siswa, tampilan modul, pemilihan warna, penggunaan jenis huruf atau font, gambar dan ilustrasi sudah sesuai dan menarik. Pada indikator tata bahasa yang digunakan, menggunakan bahasa komunikatif sudah sesuai dan ketepatan struktur kalimat. Pada indikator pemecahan soal/masalah, contoh soal dan latihan telah sesuai dengan materi dan penggunaan contoh soal yang sesuai.Pada indikator pengetahuan awal siswa, informasi tentang ilmuwan dan contoh dalam kehidupan sehari-hari telah sesuai dan jelas.

Berdasarkan dari pembahasan yang diuraikan di atas, modul yang dikembangkan dalam kategori valid dan menarik dan dapat digunakan. Pada penelitian sebelumnya yang juga mengembangkan modul, seperti pada penelitian yang dilakukan Tengku Novenia Yahya, dkk yang mengembangkan modul berbasis eksperimen sederhana dengan menggunakan strategi Physics I'm In Love (PIL) yang termasuk kategori sangat layak digunakan pada pembelajaran 
(Yahya, Nasir, \& Syahril, n.d.). Kemudian, seperti penelitian yang dilakukan oleh N. Izzati, dkk, dalam mengembangkan modul tematik dan dibuat dengan inovatif berkarakter pada materi pencemaran lingkungan yang termasuk dalam kategori sangat layak dan menambah rasa ingin tahu siswa terhadap peduli lingkungan (Izzati, Hindarto, \& Pamelasari, 2013).

Beda penelitian ini dengan penelitian sebelumnya adalah pengembangan produk berupa modul yang dibuat berdasarkan hambatan belajar siswa yang muncul ketika pembelajaran. Hambatan belajar yang sering muncul pada mata pelajaran seperti matematika, biologi dan mata pelajaran lain. Akan tetapi, modul yang dikembangkan berdasarkan hambatan belajar siswa pada pelajaran fisika, pada materi elastisitas benda dan hukum Hooke.

\section{KESIMPULAN DAN SARAN}

\section{a. Kesimpulan}

Menurut dari uraian hasil dan pembahasan di atas, maka dapat disimpulkan bahwa: 1). respon yang diberikan oleh siswa dan guru terhadap kemenarikan modul masuk dalam kriteria sangat menarik yang didapat dari hasil uji coba lapangan memperoleh persentase skor $86,12 \%$ dan hasil penilaian respon guru memperoleh persentase skor sebesar $97,20 \%$. 2). Kevalidan modul masuk dalam kriteria sangat valid yang didapat dari hasil validasi ahli materi sebesar $95,83 \%$, ahli media sebesar $82,96 \%$ dan ahli pembelajaran sebesar $80,00 \%$.

\section{b. Saran}

Saran dari penelitian ini adalah: 1) penelitian pengembangan modul berdasarkan hambatan belajar siswa dapat dikembangkan pada materi yang berbeda, 2) guru hendaknya mengidentifikasi hambatan belajar siswa agar dapat lebih mudah dalam mengembangkan sumber belajar atau media belajar yang sesuai hambatan belajar yang muncul dan diharapkan dapat digunakan untuk penunjang pembelajaran, 3) untuk peneliti agar dapat meneruskan dalam mengembangkan modul berdasarkan hambatan belajar siswa sampai ke tahap terakhir yakni tahap produksi masal.

\section{DAFTAR PUSTAKA}

Anwari, R. (2017). Desain Didaktis Interaktif Problem Solving Matematis Pada Pokok Bahasan Kesebangunan. JPPM, 10(1).

Arslan, S., Baran, D., \& Okumus, S. (2011). Brousseau's Theory of Didactical Situations in Mathematics and An Application of Adidactical Situations. Necatibey Faculty of Education Electronic Journal of Science and Mathematics Education, 5(1), 204-224.

Asyhari, A., \& Silvia, H. (2016). Pengembangan Media Pembelajaran Berupa Buletin Dalam Bentuk Buku Saku Untuk Pembelajaran IPA Terpadu. Jurnal Ilmiah Pendidikan Fisika Al-BiRuNi, 5(1), 1-13. https://doi.org/10.24042/jpifalbiruni. v5i1.100

Cavalcanti, V. de S., \& Lins, A. F. (2013). Aprendizagem Dos Conceitos Sobre Circunferência $\mathrm{Na}$ Perspectiva Da Teoria Das Situações Didáticas. Investigações em Ensino de Ciências, 18(1), 107-126.

Dedy, E., \& Sumiyaty, E. (2017). Desain Didaktis Bahan Ajar Matematika SMP Berbasis Learning Obstacle dan Learning Trajectory. Jurnal Review Pembelajaran Matematika, 2(1), 69-80.

Fatikhah, I., \& Izzati, N. (2015). Pengembangan Modul Pembelajaran Mtematika Bermuatan Emotion Quotient Pada Pokok Bahasan Himpunan. EduMa, 4(2), 46-61.

Indrawati, R. M. (2013). Peningkatan 
Aktivitas dan Hasil Belajar Materi Peristiwa Sekitar Proklamasi Melalui Bermain Peran. Journal of Elementary Education, 2(4), 15-22. Diambil dari http://journal.unnes.ac.id/sju/index.p $\mathrm{hp} / \mathrm{jee}$

Irwandani, Latifah, S., Asyhari, A., Muzannur, \& Widayanti. (2017). Modul Digital Interaktif Berbasis Articulate Studio'13: Pengembangan Pada Materi Gerak Melingkar Kelas X. Jurnal Ilmiah Pendidikan Fisika Al-BiRuNi, 6(2), 221-231. https://doi.org/10.24042/jipfalbiruni. v6i2.1862

Izzati, N., Hindarto, N., \& Pamelasari, S. . (2013). Pengembangan Modul Tematik dan Inovatif Berkarakter Pada Tema Pencemaran Lingkungan Untuk Siswa Kelas VII SMP. Jurnal Pendidikan IPA Indonesia, 2(2), 183-188. Diambil dari http://journal.unnes.ac.id/nju/index.p hp/jpii\%0A

Jamaris, M. (2015). Kesulitan Belajar Perspektif, Asesmen, dan Penanggulangannya Bagi Anak Usia Dini dan Usia Sekolah. Bogor: Ghalia Indonesia.

Lestari, K. M., Rusnayati, H., \& Wijaya, A. F. C. (2017). Profil Hambatan Belajar Epistimologis Siswa Kelas VIII SMP Pada Materi Tekanan Zat Cair Melalui Tes Kemampuan Responden. In Prosiding Seminar Nasional Fisika (E-Journal) SNF2017 (Vol. VI, hal. 31-38). Jakarta.

https://doi.org/doi.org/10.21009/03.S NF2017.01.OER.05

Rahayu, S. D., Prihandono, T., \& Gani, A. A. (2017). Pengembangan Modul Fisika Berbasis Concept Mapping Pada Materi Elastisitas di SMA. Jurnal Pembelajaran Fisika, 6(3),
240-247.

Rahdiyanta, D. (2009). Teknik penyusunan modul.

Rahmawati. (2016). Hasil TIMSS 2015.

Setiyadi, M. W., Ismail, \& Gani, H. A. (2017). Pengembangan Modul Pembelajaran Biologi Berbasis Pendekatan Saintifik Untuk Meningkatkan Hasil Belajar Siswa. EST Journal of Education Science and Technology, 3(2), 102-112.

Sugiyono. (2012). Metode Penelitian Kuantitatif Kualitatif Dan $R \& D$. Bandung: Alfabeta.

Suryana, Y., Pranata, O. H., \& Apriani, I. F. (2012). Desain Didaktis Pengenalan Konsep Pecahan Sederhana Pada Pembelajaran Matematika Untuk Siswa Kelas III Sekolah Dasar. In Seminar Nasional Matematika dan Pendidikan Matematika FMIPA UNY (hal. 1326). Yogyakarta.

Wati, W., \& Fatimah, R. (2016). Effect Size Model Pembelajaran Kooperatif Tipe Numbered Head Together (NHT) Terhadap Kemampuan Berpikir Kritis Siswa Pada Pembelajaran Fisika. Jurnal Ilmiah Pendidikan Fisika Al-BiRuNi, 5(2), 213-222.

https://doi.org/10.24042/jpifalbiruni. v5i2.121

Yahya, T. N., Nasir, M., \& Syahril. (n.d.). Pengembangan Modul PIL (Physics, I'm In Love) Berbasis Eksperimen Sederhana. Universitas Riau, Riau. Diambil dari http://journal.unnes.ac.id/nju/index.p $\mathrm{hp} / \mathrm{jpii} \% 0 \mathrm{~A}$

Yuberti. (2015). Pengembangan Media Pembelajaran Fisika Berbasis Kvisoft Flikbook Maker Yang Merujuk Pada Nilai-Nilai Keislaman di Perguruan Tinggi Negeri Lampung. Bandar Lampung. 